\title{
Suppressor of Fused Homolog
}

National Cancer Institute

\section{Source}

National Cancer Institute. Suppressor of Fused Homolog. NCI Thesaurus. Code C97821.

Suppressor of fused homolog (484 aa, $\sim 54 \mathrm{kDa}$ ) is encoded by the human SUFU gene.

This protein plays a role in both the hedgehog pathway and transcriptional modulation. 